Materiales de Construcción

Vol. 70, Issue 337, January-March 2020, e211

ISSN-L: $0465-2746$

https://doi.org/10.3989/mc.2020.07519

\title{
Clayey soil stabilization using alkali-activated cementitious materials
}

\author{
J.F. Rivera ${ }^{\mathrm{a}} \bowtie$, A. Orobio $^{\mathrm{b}}$, R. Mejía de Gutiérrez ${ }^{\mathrm{a}}$, N. Cristelo $^{\mathrm{c}}$ \\ a. GMC (CENM), School of Materials Engineering, Universidad del Valle, Cali (Colombia) \\ b. Applied Research in Construction Group (GRUA), School of Civil Engineering, Universidad del Valle, Cali (Colombia) \\ c. CQVR, Department of Engineering, University of Trás-os-Montes e Alto Douro, Vila Real (Portugal) \\ $\triangle$ jhonathan.rivera@correounivalle.edu.co
}

Received 24 May 2019 Accepted 16 September 2019 Available on line 13 February 2020

\begin{abstract}
In this study, a clayey soil classified as A-7-5 according ASTM D3282, was stabilized using alkaliactivated cementitious materials (AAC) added to the soil dry in percentages of 20 and $30 \%$. Fly ash (F1, F2) with high unburned carbon content (up to $38.76 \%$ ), hydrated lime (L) and granulated blast furnace slag were used. Unconfined compressive strength and flexural strength at 28 days of curing and the durability after 12 wetting-drying cycles were evaluated. The results were compared with a soil-cement reference mixture. The soil treated with AAC-F1L showed a volume expansion of $0.51 \%$ and volume contraction of $-0.57 \%$ compared with the $0.59 \%$ expansion and $-0.68 \%$ contraction of the soil-cement reference mixture. Additionally, the mass loss after the wetting and drying cycles is only $3.74 \%$ which is slightly lower than the mass loss of the soil stabilized with ordinary Portland cement (OPC) (3.86\%) and well below the value specified in Colombian regulations ( $7 \%$ ).
\end{abstract}

KEYWORDS: Soil stabilization; Clayey soil; Alkali-activated cement; Fly ash; Blast furnace slag.

Citation/Citar como: Rivera, J.F.; Orobio, A.; Mejía de Gutiérrez, R.; Cristelo, N. (2020) Clayey soil stabilization using alkali-activated cementitious materials. Mater. Construcc. 70 [337], e211 https://doi.org/10.3989/mc.2020.07519

RESUMEN: Estabilización de suelo arcilloso utilizando materiales cementicios activados alcalinamente. En este estudio, un suelo arcilloso clasificado como A-7-5 según ASTM D3282, se estabilizó utilizando materiales activados alcalinamente (AAC) en porcentajes de 20 y 30\%. Se utilizaron cenizas volantes (F1, F2) con alto contenido de inquemados (hasta $38,76 \%$ ), cal hidratada (L) y escoria granulada de alto horno. Se evaluó la resistencia a la compresión confinada y la resistencia a la flexión a 28 días de curado y la durabilidad después de 12 ciclos de humectación-secado. Los resultados se compararon con una mezcla de referencia suelo-cemento. El suelo tratado con AAC-F1L mostró una expansión y contracción volumétrica del $0,51 \%$ y $-0,57 \%$ respectivamente, en comparación con el $0,59 \%$ y - $0,68 \%$ de la mezcla de referencia suelo-cemento. Además, la pérdida de masa después de los ciclos de humectación y secado es sólo 3.74\%, valor ligeramente inferior a la del suelo estabilizado con cemento Portland (3.86\%) y muy inferior al valor especificado en la normativa colombiana $(7 \%)$.

PALABRAS CLAVE: Estabilización de suelos; Suelo arcilloso; Cemento activado alcalinamente; Cenizas volantes; Escorias granuladas de horno alto.

ORCID ID: J.F. Rivera (http://orcid.org/0000-0003-0395-1517); A. Orobio (http://orcid.org/0000-0001-7166-3061); R. Mejía de Gutiérrez (http://orcid.org/0000-0002-5404-2738); N. Cristelo (http://orcid.org/0000-0002-3600-1094)

Copyright: (C) 2020 CSIC. This is an open-access article distributed under the terms of the Creative Commons Attribution 4.0 International (CC BY 4.0) License. 


\section{INTRODUCTION}

Soil stabilization is primarily used to improve the geotechnical properties of a native soil. Improved properties such as mechanical strength, bearing capacity, permeability and durability facilitate use of the stabilized soil in many engineering applications, as either subgrade or subbase in the construction of roads and railways and in foundations, dams, and embankments. In general, there are several methods to physically or mechanically improve the properties of a native soil; however, "stabilization" is essentially the improvement of soil properties with the incorporation of chemical additives to the soil.

The basic principles of soil stabilization through chemical additives originated in the late 1950s when scientists first used hydrated lime and Portland cement to stabilize expansive clays and even produced lime-fly ash combinations with the same objective (1). Currently, the use of Portland cement and lime to stabilize a wide range of soils for various engineering applications is still a very popular and widespread method. However, these materials have environmental impacts associated with $\mathrm{CO}_{2}$ emissions, high energy consumption and high cost in certain applications. Therefore, there have been attempts to diversify the stabilizing agents to provide a greater variety of materials for such applications; those attempts include certain industrial by-products (fly ash, slag, cement kiln dust and glass), certain wastes (from demolition, tires, and calcium carbide) and polymer products (polymeric fibres, asphalt products, and bituminous products) (2).

Recently, the alkaline activation process as an option for the stabilization of various types of soils has gained prominence since many of the precursor materials of alkali-activated cements originate from industrial by-products or waste (3). This initiative emerged due to the environmental problems and costs associated with the use of lime and Portland cement $(4,5)$. However, the alkali-activated cementitious materials may have similar or better performances than traditional cements and similar hardening times for these applications.

Several laboratory studies have been carried out in recent years using the alkaline activation process to stabilize different types of soil with promising results. Wilkinson et al. (2010) (6) carried out a study where they used activated fly ash, slag and hydrated lime to stabilize clayey soils collected across Australia. In that study, soil stabilized with ground granulated blast-furnace slag (GGBS) gained greater strength at early ages compared with soils stabilized with fly ash or hydrated lime in the same proportions. Cristelo et al. (2012) (7) studied the effect of calcium content on marl (also called marlstone) soils stabilized with class $\mathrm{C}$ and $\mathrm{F}$ fly ash alkali-activated with sodium hydroxide solutions. The results showed that in short times, the mixtures with class $\mathrm{C}$ ash gained more strength compared with the mixtures of soil with class $\mathrm{F}$ ash due to the high calcium content of the mixtures with class $\mathrm{C}$ ash; however, at older ages, the soils stabilized with class $\mathrm{F}$ ashes exhibited higher mechanical strengths. Cristelo et al. (2012) (8) also studied the effect of the type and concentration of the activator on the stabilization of the residual granitic soils with class F fly ash and concluded that the $\mathrm{Na}_{2} \mathrm{O}$ :ash ratio has an important role in the development of mechanical strength and that the maximum strength values are achieved when this parameter is optimized.

There were no improvements reported when superplasticizer additives or $\mathrm{NaCl}$ were used in mixtures with soil; additionally, the use of $\mathrm{Ca}(\mathrm{OH})_{2}$ resulted in short-term high mechanical strength. Sargent et al. (2013) (9) conducted a study on the improvement of the mechanical properties and durability of an artificial silty sand soil using alkaliactivated industrial wastes such as cementitious materials; among these materials were pulverized fly ash (PFA), GGBS and red gypsum (RG), which were activated with an $\mathrm{NaOH}$ and $\mathrm{Na}_{2} \mathrm{SiO}_{3}$ solution. This study reported that the soil stabilized with GGBS had the best properties in terms of mechanical strength and durability; the authors suggested that soils stabilized with GGBS-PFA and GGBS-RG, from an engineering standpoint, can be used in applications where high stiffness is not required to prevent fracture of the stabilized soil.

Zhang et al. (2013) (10) studied the feasibility of using alkali-activated metakaolin (MK) as an alternative cementitious material to stabilize lowplasticity clayey soil; the results showed that the compressive strength, failure strain, Young's modulus and shrinkage decreased. The ductility of the soil stabilized with MK makes the soil far more effective at mitigating crack formation and in applications where compaction is required.

In stabilized and compacted soil applications, the maximum dry density and optimum moisture content have significant impacts on the final properties of the mixture. The maximum dry density varies with the addition of cementitious material and tends to decrease. This effect is related to the flocculation of the soil particles, since particle flocculation in the structure of compacted soil increases porosity; however, as time passes, the pozzolanic reactions fill these porosities with reaction products that help cement the structure (11).

The conditions of the stabilized soils in the laboratory tests are crucial when soils are stabilized with alkali-activated cementitious materials. Ghadir and Ranjbar (2018) (12) conducted a study of soils stabilized with alkali-activated volcanic ash, in which uniaxial compression tests were performed on specimens with the optimal moisture in the mixture and in dry conditions. The results showed that the alkaliactivated ash was more efficient under dry curing 
conditions since this sample improved soil resistance by $200 \%$ compared with the soil stabilized with Portland cement, whereas under optimal humidity conditions, Portland cement improved resistance by $33 \%$ compared with the soil stabilized with volcanic ash. This difference is associated with the effect of water and $\mathrm{pH}$ on the kinetics of the alkaline activation reactions of the volcanic ash.

This study evaluated the chemical stabilization of a clayey soil using alkali-activated fly ash-based cementitious materials. Mixtures of fly ash/granulated blast-furnace slag (GBFS) and fly ash/lime activated with $\mathrm{NaOH} / \mathrm{Na}_{2} \mathrm{SiO}_{3}$ solution were used. The results of the laboratory tests, unconfined compressive strength (UCS), flexural strength (FS) and durability were compared with those obtained for the soil stabilized with Portland cement and used as reference system.

\section{MATERIALS AND METHODOLOGY}

\subsection{Materials}

The soil used was collected in southern Cali, Valle del Cauca, Colombia, at latitude $3^{\circ} 21^{\prime} 45.979$ 'N and longitude $76^{\circ} 30^{\prime} 53.277^{\prime}$ 'W. It was initially dried at ambient temperature, and a disc mill was used to de-flocculate the particles. The particle size distribution was determined by sieving, according to ASTM D6913-17 (13), the sieved material showed a very fine texture with $96.75 \%$ of the material passed through sieve number 200. The Atterberg limits were determined according ASTM D4318-17 (14). The soil presented liquid limit of $58 \%$ and plastic limit of $34 \%$. The Plasticity Index calculated was $24 \%$. These results were used to classify the soil as a A-7-5 according to ASTM D3282-15 (15).

For the preparation of the alkali-activated binding pastes, GBFS and commercial lime were used as sources of calcium, and two classes of fly ash (FA1, FA2) were used as precursors. The FA1, FA2 and GBFS were previously milled for $2 \mathrm{~h}$; after which the average particle size after the grinding process of the precursors was $37.064 \mu \mathrm{m}, 24.968 \mu \mathrm{m}$ and $27.729 \mu \mathrm{m}$, respectively. The commercial lime had an average particle size of $24.740 \mu \mathrm{m}$. A general-use Portland cement (OPC) was also included in the study as reference material. Table 1 shows the chemical composition of the materials used that was determined by X-ray fluorescence (XRF) using a Philips PW-2440 Pro PANalitical MagiX spectrometer, with a maximum power of $4 \mathrm{~kW}$ and equipped with a rhodium tube. A NaOH/Na $\mathrm{Na}_{2} \mathrm{SiO}_{3}$ combination, in solution form, was used as the alkaline activator.

\subsection{Development of the alkali-activated binding pastes}

Two alkali-activated binding pastes (F1L and F2G) were designed using response surface models where the $\mathrm{SiO}_{2} / \mathrm{Al}_{2} \mathrm{O}_{3}$ and $\mathrm{Na}_{2} \mathrm{O} / \mathrm{SiO}_{2}$ molar ratios were considered as the independent variables. The pastes were cured at $30^{\circ} \mathrm{C}$. The uniaxial compressive strength (UCS) after 28 days was defined as the dependent variable. The response surface models were optimized to obtain the best combination of independent variables and maximize the response of the dependent variable, producing the contour plots shown in Figure 1.

F1L (Figure 1a) is composed by $80 \%$ FA1 and $20 \%$ lime, with optimized independent variables $\mathrm{SiO}_{2} / \mathrm{Al}_{2} \mathrm{O}_{3}=3.0$ and $\mathrm{Na}_{2} \mathrm{O} / \mathrm{SiO}_{2}=0.3$, yielding an UCS, after 28 days, of $21 \mathrm{MPa}$. F2G (Figure $1 \mathrm{~b}$ ) is composed by $80 \%$ FA2 and $20 \%$ GBFS, with optimized independent variables $\mathrm{SiO}_{2} / \mathrm{Al}_{2} \mathrm{O}_{3}=3.9$ and $\mathrm{Na}_{2} \mathrm{O} / \mathrm{SiO}_{2}=0.32$, yielding an UCS, after 28 days, of $23 \mathrm{MPa}$.

\subsection{Preparation of the stabilized soil test specimens and testing}

Modified Proctor compaction tests were performed to determine the maximum dry density (MDD) and optimum moisture content (OMC) of

TABLE 1. Chemical compositions of the materials used as precursors, calcium sources and soil.

\begin{tabular}{lcccccc}
\hline Compound (wt.\%) & FA 1 & FA 2 & GBFS & Lime & OPC & Soil \\
\hline $\mathrm{SiO}_{2}$ & 28.11 & 28.53 & 37.74 & 2.48 & 21.23 & 40.64 \\
$\mathrm{Al}_{2} \mathrm{O}_{3}$ & 17.47 & 19.18 & 15.69 & 0.91 & 4.92 & 20.96 \\
$\mathrm{Fe}_{2} \mathrm{O}_{3}$ & 5.27 & 8.80 & 1.85 & 0.39 & 4.88 & 21.34 \\
$\mathrm{CaO}$ & 2.34 & 6.68 & 40.30 & 54.48 & 64.27 & 1.49 \\
$\mathrm{SO}_{3}$ & 3.73 & 2.70 & - & 0.43 & - & - \\
$\mathrm{MgO}$ & 0.83 & 2.24 & 1.3 & 0.30 & 1.61 & 1.86 \\
$\mathrm{TiO}_{2}$ & 1.03 & 1.62 & 0.5 & 0.05 & 0.24 & 1.81 \\
$\mathrm{Na}_{2} \mathrm{O}$ & 1.09 & 7.94 & 0.2 & 0.11 & 0.26 & 0.48 \\
$\mathrm{LOI}$ & 38.76 & 20.67 & - & 40.37 & - & 10.57 \\
\hline
\end{tabular}



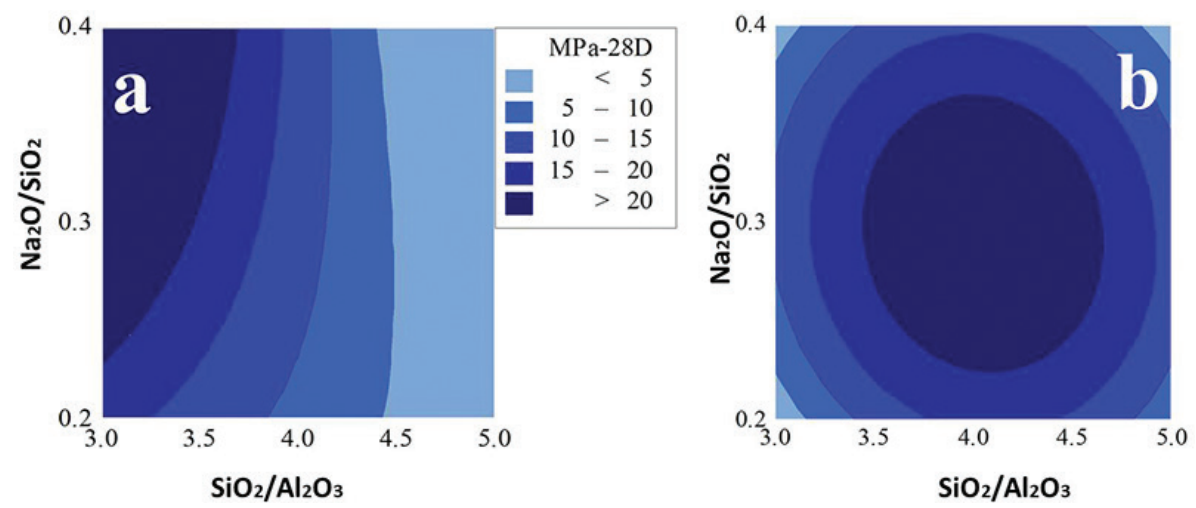

FIGURE 1. Optimization of the synthesis variables of alkali-activated cementitious materials a) F1L and b) F2G.

each mixture, according to ASTM D1557-12e1 (16). The binding paste was added to the dry soil in predetermined percentages. The soil-cement mixture was prepared with $13 \mathrm{wt} . \%$ of OPC, which was the content required for the compaction test according to the classification of the soil (17). The soils stabilized with alkali-activated pastes were mixed with $20 \% \mathrm{~F} 1 \mathrm{~L}, 30 \% \mathrm{~F} 1 \mathrm{~L}$ and $30 \% \mathrm{~F} 2 \mathrm{G}$.

The soil and the precursor, both in dry state, were manually mixed until a uniform coloration was obtained, for homogenisation. The alkaline activator, calculated as a function of the precursor content, was then slowly, while still mixing. Finally, additional water was added, to guarantee the predetermined OMC for each mixture.

The specimens were then made by compacting the material into cylindrical moulds, with $52 \mathrm{~mm}$ in diameter and $104 \mathrm{~mm}$ in height, and prismatic moulds with $50 \times 50 \times 150 \mathrm{~mm}$, according to ASTM D1632-17 (18). Once compacted, the specimens were cured in a climatic chamber, with a temperature and humidity of $30{ }^{\circ} \mathrm{C}$ and $80 \%$, respectively. UCS tests were performed after 7 and 28 days curing, and flexural tests after 28 days, based on ASTM D1633-17 and D1635-12 (19, 20), respectively, in an INSTRON 3300 universal testing machine.

Wetting and drying tests were performed on stabilized soils after 7 days of curing, following the protocol, outlined in ASTM D559-15 (21). Each specimen was subjected to a total of 12 wettingdrying cycles. One full cycle consisted of immersion in potable water for $5 \mathrm{~h}$ and then drying for $48 \mathrm{~h}$ at $71^{\circ} \mathrm{C}$. This test was done to calculate the changes in the volumes of the stabilized soil specimens and the mass loss during the wetting and drying cycles. The volume change was calculated by measuring (in saturated and dry conditions) the average height and diameter of one of the specimens. To calculate the mass loss, the second specimen in the dry condition was brushed in each cycle with a steel brush applying an average force of $15 \mathrm{~N}$, passing 20 times over the lateral surface of the body and four times over each face of the specimen.

\section{RESULTS AND DISCUSSION}

\subsection{Compaction}

The compaction curves for each stabiliser type and content used are shown in Figure 2, and the MDD / OMC of all tests is presented in Table 2. The MDD of the nonstabilized compacted soil is $1.56 \mathrm{~g} / \mathrm{cm}^{3}$, and the OMC of this sample is $24.67 \%$. The addition of OPC as stabilizer increases the MDD to $1.59 \mathrm{~g} / \mathrm{cm}^{3}$ with an OMC of $26.15 \%$; this phenomenon is related to the addition of a material of higher specific weight to the mixture, and the increase in the moisture content is attributed to the additional water the OPC requires to begin the hydration processes (22). In contrast, by stabilizing the soil using alkali-activated cements, in general, the MDD decreases, compared to the nonstabilized soil.

The addition of $30 \mathrm{~F} 1 \mathrm{~L}$ and $30 \mathrm{~F} 2 \mathrm{G}$ produced slightly different results, with $1.47 \mathrm{~g} / \mathrm{cm}^{3}$ and $26.92 \%$ for the former, and $1.51 \mathrm{~g} / \mathrm{cm}^{3}$ and $26.27 \%$ for the latter. FA1 is the precursor of the $30 \mathrm{~F} 1 \mathrm{~L}$ system, and the loss-on-ignition (LOI) (unburned carbon) of this sample is $38.76 \%$, while FA2 is the precursor of $30 \mathrm{~F} 2 \mathrm{G}$ with an LOI of $20.67 \%$. Additionally, the proportions of calcium sources for both cements are the same, $20 \%$ by weight, but are of different nature and composition. 30F1L contains lime, and $30 \mathrm{~F} 2 \mathrm{G}$ contains GBFS, which theoretically makes the specific gravity of cementitious material $30 \mathrm{~F} 2 \mathrm{G}$ higher than that of $30 \mathrm{~F} 1 \mathrm{~L}(23,24)$. For the OMC of the soil stabilized with $30 \mathrm{~F} 1 \mathrm{~L}$, this mixture has a slightly higher $\mathrm{OMC}$ than that of $30 \mathrm{~F} 2 \mathrm{G}$; according to Osinubi (2006) (25), lime content increases the OMC of clayey soils.

The MDD is also affected by the content of cementitious material used to stabilize the soil. With the addition of $20 \mathrm{~F} 1 \mathrm{~L}$, the MDD was $1.50 \mathrm{~g} / \mathrm{cm}^{3}$, 


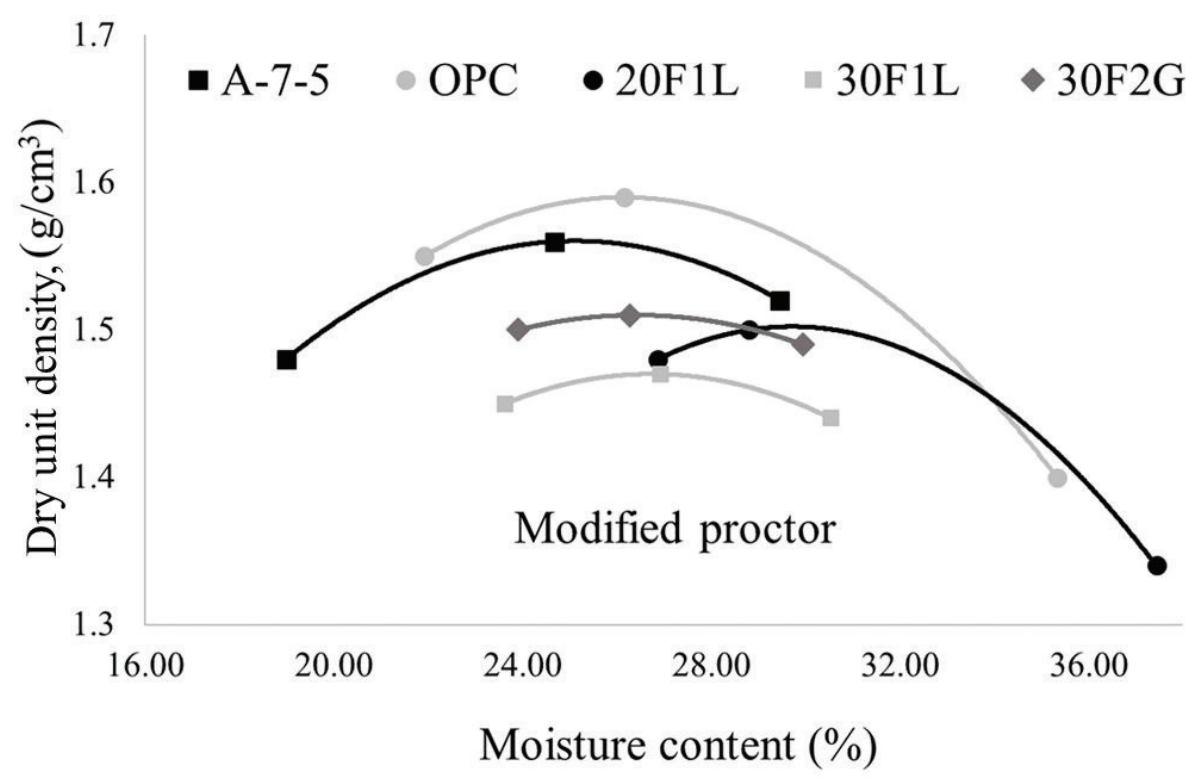

Figure 2. Proctor curves.

TABLE 2. MDD and OMC of the original soil and the soil-stabiliser combinations.

\begin{tabular}{lccc}
\hline Material & $\begin{array}{c}\text { Binder } \\
\text { content } \mathbf{( \% )}\end{array}$ & $\begin{array}{c}\text { MDD } \\
\left(\mathbf{g} / \mathbf{c m}^{3}\right)\end{array}$ & $\begin{array}{c}\text { OMC } \\
(\mathbf{\%})\end{array}$ \\
\hline A-7-5 & - & 1.56 & 24.67 \\
OPC & 13 & 1.59 & 26.15 \\
20F1L & 20 & 1.50 & 28.81 \\
30F1L & 30 & 1.47 & 26.92 \\
30F2G & 30 & 1.51 & 26.27 \\
\hline
\end{tabular}

which is slightly higher than the $1.47 \mathrm{~g} / \mathrm{cm}^{3}$ of the soil stabilized with $30 \mathrm{~F} 1 \mathrm{~L}$ (Table 2), and is consistent with reports from certain authors $(11,22)$. Regarding the materials used, one of the reasons why the MDD decreases between $20 \% \mathrm{~F} 1 \mathrm{~L}$ and $30 \% \mathrm{~F} 1 \mathrm{~L}$, is the amount of unburned material in the precursor (fly ash 1 with $38.76 \%$ LOI), which results in a mixture with lower specific gravity.

\subsection{Uniaxial compressive strength (UCS)}

Figure 3 shows the UCS results of the unsaturated and saturated specimens. For the unsaturated conditions (Figure 3a), the reference mixture (OPC) registered the best performance after 7 days $\left(\mathrm{UCS}_{7 \mathrm{D}}=4.79 \mathrm{MPa}\right)$, compared with the values obtained using alkali-activated cementitious materials $20 \mathrm{~F} 1 \mathrm{~L}, 30 \mathrm{~F} 1 \mathrm{~L}$ and $30 \mathrm{~F} 2 \mathrm{G}$, with $\mathrm{UCS}_{7 \mathrm{D}}$ of $3.88,4.21$ and $1.52 \mathrm{MPa}$, respectively. This trend continues after 28 days, with OPC, $20 \mathrm{~F} 1 \mathrm{~L}, 30 \mathrm{~F} 1 \mathrm{~L}$ and $30 \mathrm{~F} 2 \mathrm{G}$ showing $\mathrm{UCS}_{28 \mathrm{D}}$ values of 6.55 , 5.26, 4.45 and $2.43 \mathrm{MPa}$, respectively. There are two key factors explaining why the performance of the soil treated with alkali activated cementitious material is worse than that of the reference sample (OPC). One factor is the compositions of the main precursor materials (FA1 and FA2), and the other factor is the chemical composition of the soil. As shown in Table 1, the content of unburned carbon (LOI) is quite high in both ashes $($ FA $1=38.76 \%$ and FA $2=20.67 \%)$. This carbon content may have a negative impact when the mixture of cementitious material and soil is alkali activated because carbon has a large surface area that absorbs a certain amount of the alkaline activator and removes alkali cations, hindering the kinetics of the dissolution reactions of the precursor, condensation and polymerization of cementitious gels (26-28). The chemical composition of the soil (Table 1) may also have an adverse effect on the strength development of the soil stabilized with alkali-activated pastes due to the laterization degree. This is estimated by calculating the ratio of silicon to sesquioxides $\left(\mathrm{SiO}_{2} /\left(\mathrm{Al}_{2} \mathrm{O}_{3}+\mathrm{Fe}_{2} \mathrm{O}_{3}\right)\right)$ (22). The soil used in this study has a ratio of 0.96 , this means that the chemical weathering process of the soil is quite advanced due to its high amount of iron and aluminium oxides. Certain studies indicate that reactive $\mathrm{Fe}_{2} \mathrm{O}_{3}$ may precipitate much faster than $\mathrm{Al}$ or Si compounds under highly alkaline conditions and generates iron hydroxides or oxyhydroxides that consume the $\mathrm{OH}^{-}$ions of the alkaline activator, which slows the dissolution of the remaining particles of the precursor material and reduces the number of nucleation sites of the oligomers that form the cementitious aluminosilicate gel. However, other studies suggest that $\mathrm{Fe}^{+3}$ acts as nucleation sites since in silicate glasses, $\mathrm{Fe}^{+3}$ 
is known as a network former due to a charge and ionic radius similar to those of $\mathrm{Al}^{+3}(29-32)$.

Regarding the soils stabilized with the same type of alkaline cementitious material but at different proportions, in unsaturated conditions, $20 \mathrm{~F} 1 \mathrm{~L}$ has a higher UCS than $30 \mathrm{~F} 1 \mathrm{~L}$ at 28 days of curing $\left(20 \mathrm{~F} 1 \mathrm{~L} \mathrm{UCS} \mathrm{UCD}_{28 \mathrm{D}}=5.26\right.$ vs. $30 \mathrm{~F} 1 \mathrm{~L} \mathrm{UCS}_{28 \mathrm{D}}=4.45$ $\mathrm{MPa})$. The reason for this difference is not clear; however, an increase of $20 \%$ to $30 \%$ in the proportion of cementitious material leads to a slight decrease in the maximum dry density of the compacted mixture (Figure 2). The greater proportion of unburned carbon acts as a "lubricant" between the soil particles and decreases the internal friction between the particles, which affects the resistance to external stresses $(33,34)$. In contrast, the cementation capability of the $30 \mathrm{~F} 2 \mathrm{G}$ is lower than that of $30 \mathrm{~F} 1 \mathrm{~L}$, even though the maximum dry density of the mixture is higher (Table 2). This behaviour is attributed to the effect of the lime on the composition of cementitious material 30F1L. Double charge cations such as $\mathrm{Ca}^{++}$and $\mathrm{Mg}^{++}$can generate nucleation sites quickly without needing the species from the main precursor (FA1) to dissolve, due to the action of the alkaline activator; therefore, the particle agglomeration and cementation of the stabilized soil improves with shorter setting times $(35,36)$.

Figure $3 \mathrm{~b}$ shows the results of the UCS tests under water-saturated conditions. The untreated soil completely collapses after a few minutes of immersion in water, and in general, for the different cementitious materials, the compacted specimens maintain their integrity during the saturation period of $4 \mathrm{~h}$ before the test, due to the type of bonds that the cementation produces, which are not present in the untreated soil. The untreated soil has a flocculated structure; this condition creates clay bridges by electrostatic attraction, which provides strength to the material, but the strength is lost when the degree of saturation increases. The structure of the stabilized soils has cementation bonds that make the soil stiffer and stronger. When the soil is saturated, the precipitates can dissolve and gradually break the bonds. The loss of such bonds is slower in stabilized soil than in nonstabilized soil.

In the saturated conditions, the soil stabilized with OPC has the best performance at both 7 and 28 days of curing, $\mathrm{UCS}_{7 \mathrm{D}}=2.5$ and $\mathrm{UCS}_{28 \mathrm{D}}=2.7 \mathrm{MPa}$, respectively. For the saturated conditions, increasing the proportion of alkaline cementitious material F1L from $20 \%$ to $30 \%$ impacts the performance of the stabilized soil $\left(20 \mathrm{~F} 1 \mathrm{~L} \mathrm{UCS}_{7 \mathrm{D}}=1.09 ; \mathrm{UCS}_{28 \mathrm{D}}=\right.$ $1.26 \mathrm{MPa}$ vs. $30 \mathrm{~F} 1 \mathrm{~L} \mathrm{UCS}_{7 \mathrm{D}}=1.36 ; \mathrm{UCS}_{28 \mathrm{D}}=1.54$ $\mathrm{MPa}$ ) and improves the soil strength with $30 \mathrm{~F} 1 \mathrm{~L}$, $\mathrm{UCS}_{7 \mathrm{D}}=19.85 \%$ and $\mathrm{UCS}_{28 \mathrm{D}}=18.18 \%$. As mentioned above, this behaviour can be attributed to the proportion of lime in the alkaline cementitious material 30F1L. Despite the increase in the proportion of unburned carbon in the mixture, the lime immediately reacts with the soil, flocculates, and generates nucleation sites that help cement the soil structure. This effect could change the size and distribution of the pores of the compacted material, thus increasing the tortuosity and decreasing the saturation occurring during the time the sample is immersed in water $(37,38)$. Regarding the treatment with $30 \mathrm{~F} 2 \mathrm{G}$, the soil resists the saturation period much better than the untreated soil, but the strength of this soil is the lowest recorded, either after 7 or 28 days $\left(30 \mathrm{~F} 2 \mathrm{G} \mathrm{UCS} \mathrm{UCD}_{7 \mathrm{D}}=0,66 ; \mathrm{UCS}_{28 \mathrm{D}}=0,70 \mathrm{MPa}\right)$, and the specimens showed substantial deterioration during the saturation process.
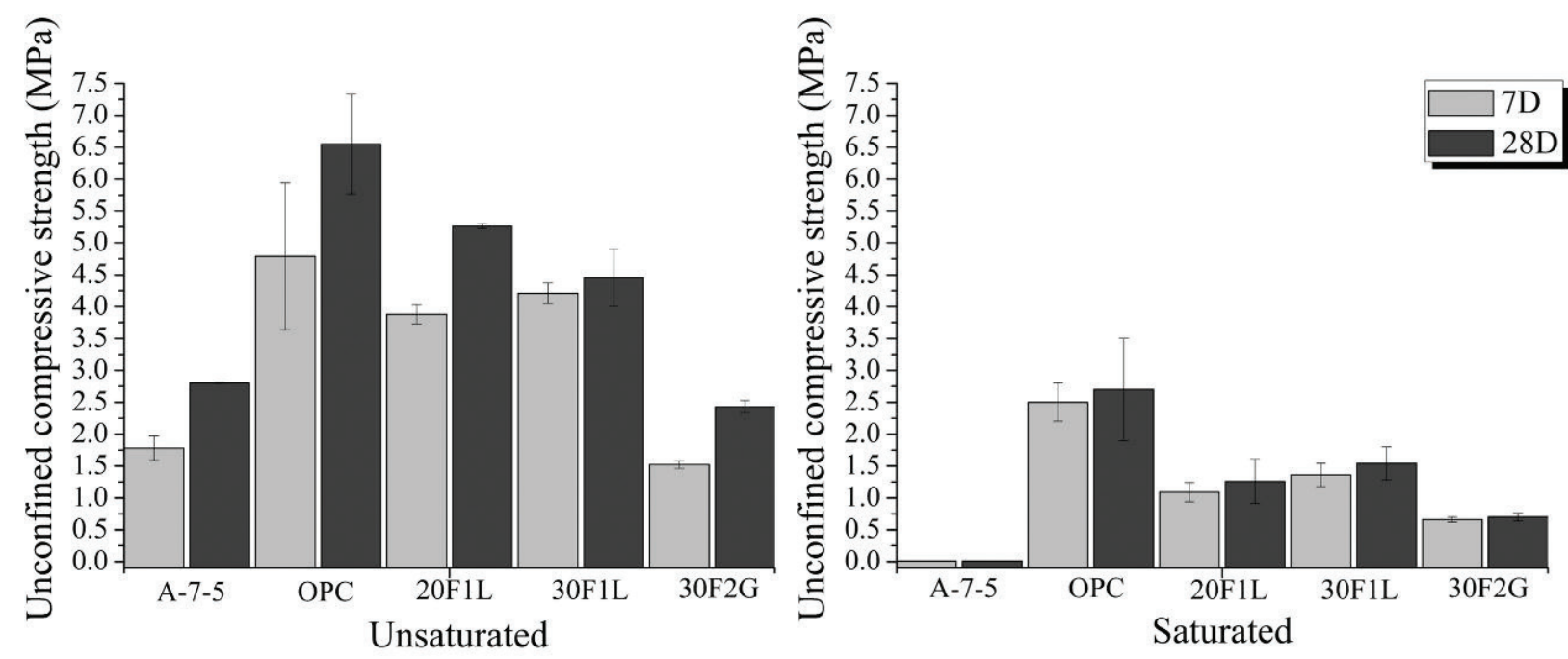

FIGURE 3. UCS of the soil under a) unsaturated and (b) saturated conditions. 


\subsection{Flexural strength (FS)}

The FS of the stabilized soil is directly related to the UCS and MDD. The evolution of the FS over the curing period is moderate, compared with that of the UCS. Figure 4 shows the FS for each mixture of stabilized soil. In general, the FS of the different cementitious materials is between $1 / 3$ and $1 / 5$ of the UCS, except that of $20 \mathrm{~F} 1 \mathrm{~L}$, which is below this range $(1 / 6$ at $0.84 \mathrm{MPa})$.

Studies by Mandal et al. (2018) (39) showed that soils stabilized with different cementitious materials and compacted at low densities had low FS values. However, in these studies, the effect of cementitious materials and the proportion of these materials in the mixture also affected the FS, together with the MDD. When the same alkaline cementitious material is used, although in different proportions, the FS increases (20F1L; FS = 0.84 MPa vs. 30F1L; FS = 0.99 MPa). Such improvement is due to the overall increase in the number of cemented particles. As mentioned above, a higher lime content increases the agglomeration and cementation capability of the soil with cementitious material $30 \mathrm{~F} 1 \mathrm{~L}$, improving the ability of this soil to dissipate energy in the bending (38). Furthermore, by changing the type of alkaline cementitious material, even if the same content is used, the FS varies $(30 \mathrm{~F} 1 \mathrm{~L}=0.99 \mathrm{MPa}$ vs. $30 \mathrm{~F} 2 \mathrm{G}=0.46 \mathrm{MPa})$. This is attributed to the agglomeration and hardening effect of the cementitious material. In these types of soils, 30F1L provides better cementation than 30F2G. Therefore, in addition to MDD and UCS, the nature and cementing capability of the cementitious material is essential to improve the FS (40).

\subsection{Wetting and drying tests (WDTs)}

Figure 5 shows the volumetric variation of the soils stabilized with different cementitious materials subjected to wetting and drying cycles. The volumetric variation of the soil stabilized with OPC is quite uniform overall. In the first cycle, it expands $0.56 \%$ and contracts $-1.90 \%$, compared with the initial volume of the specimen after 7 days curing. The rest of the expansion and contraction measurements are made with respect to the last calculated volume, which means that, after 12 cycles, the reference specimen has an average expansion of $0.59 \%$ and average contraction of $-0.68 \%$.

The soil stabilized with $20 \mathrm{~F} 1 \mathrm{~L}$ has an initial expansion of $0.74 \%$ and contraction of $-1.99 \%$ after the first cycle. Compared with the soil stabilized with OPC, the change in the volume of the soil with $20 \mathrm{~F} 1 \mathrm{~L}$ is greater in both expansion and contraction and, at the end of the 12 cycles, an average expansion / contraction of $0.84 \%$ and $-0.93 \%$ was determined. The volumetric variation of the soil stabilized with $20 \mathrm{~F} 1 \mathrm{~L}$ is far more irregular than the soil-OPC.

The soil stabilized with $30 \mathrm{~F} 1 \mathrm{~L}$ has an expansion of $0.17 \%$ and a contraction of $-0.97 \%$ in the first cycle and, on average, a volume changes slightly lower than that of the OPC and $20 \mathrm{~F} 1 \mathrm{~L}$, with an expansion of $0.51 \%$ and a contraction of $-0.57 \%$. The test of the soil stabilized with $30 \mathrm{~F} 2 \mathrm{G}$ was discarded because the specimen collapsed completely in the second wetting and drying cycle, and it was not possible to determine the corresponding weight and measurements.

The expansion and contraction limits proposed by Nogami \& Villibor (41), for paving tropical lateritic soils without stabilization, are used in the present work as a reference (Table 3). This is in accordance with the Rojas et al. (2008) (42) proposal, based on the lack of standard parameters to assess the volumetric variation of stabilized soils. Overall, based on these data, at the end of the WDT cycles, the expansion and contraction

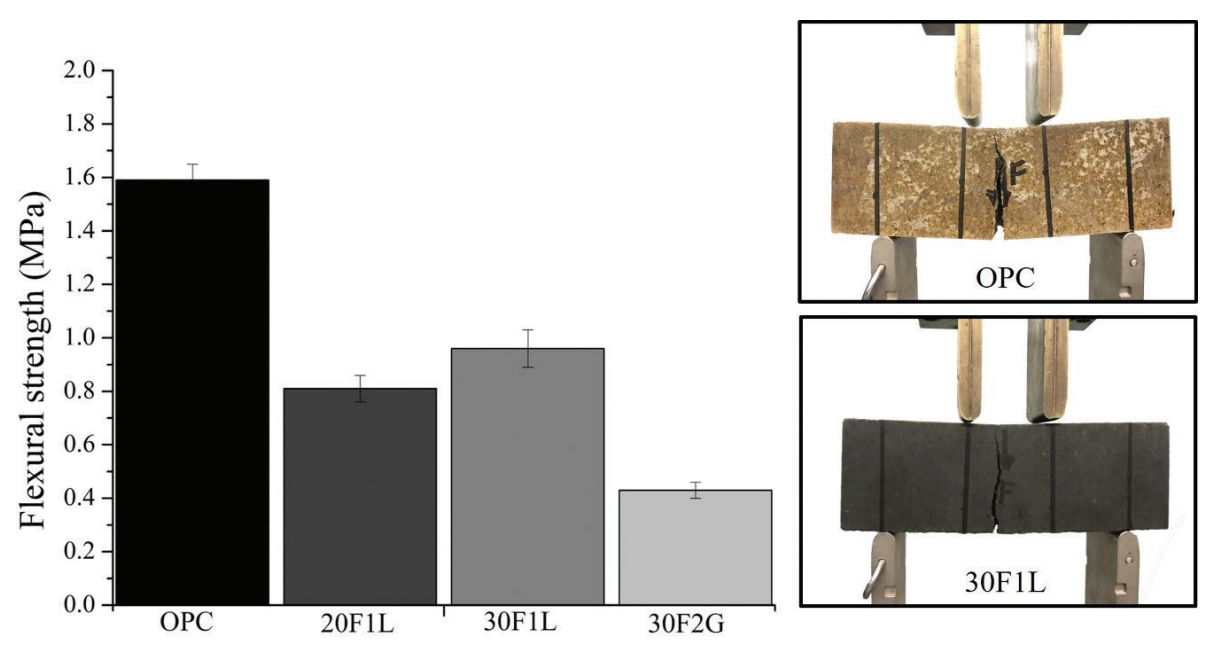

FIGURE 4. Flexural strength. 


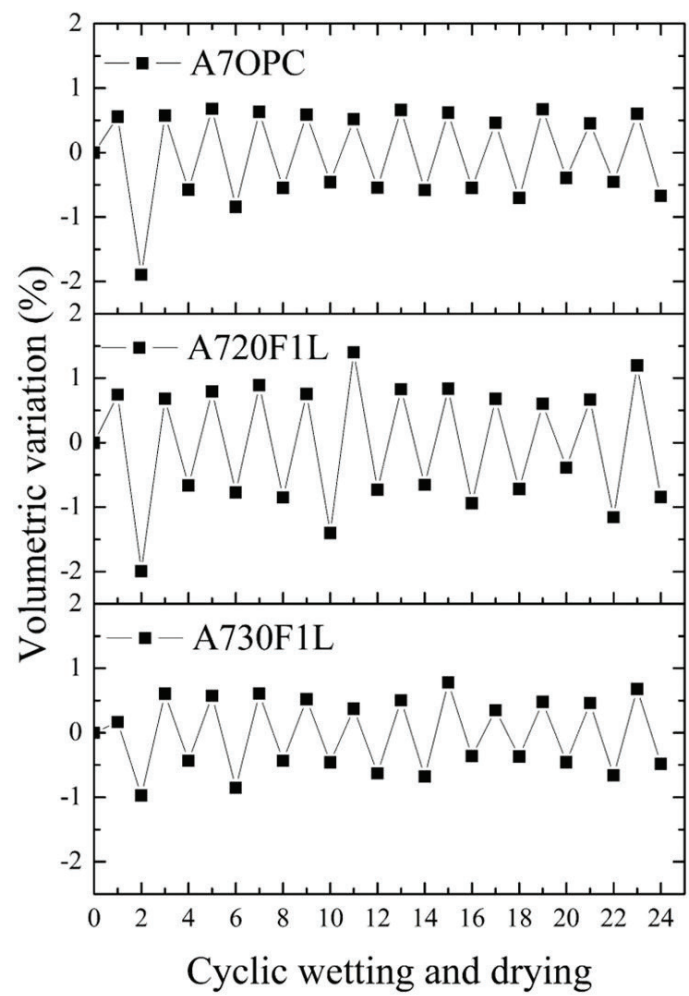

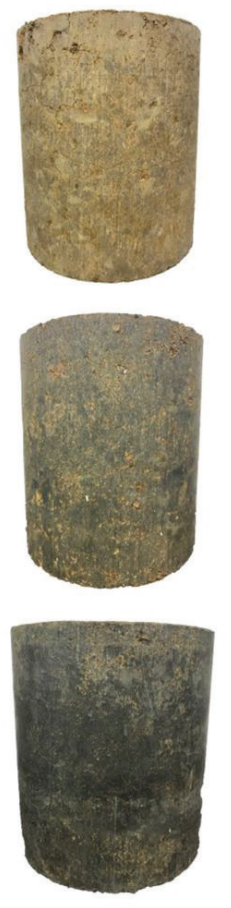

Cycle \#1

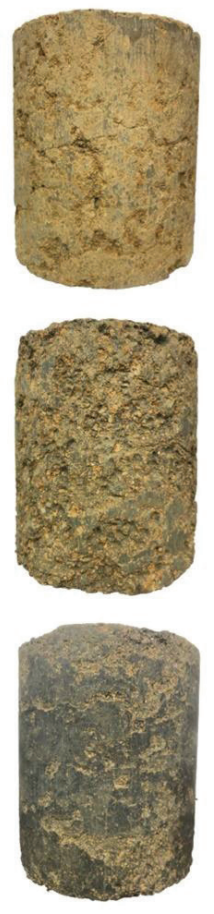

Cycle \#12

FIGURE 5. Volumetric variation and mass loss for the wetting and drying cycles.

TABLE 3. Volumetric change of untreated lateritic soils. Adapted from Nogami \& Villibor (41).

\begin{tabular}{lc}
\hline Nivel of Expansion or Contraction & Percentage, $\%$ \\
\hline High & $>3$ \\
Average & 0.5 to 3 \\
Low & $<0.5$ \\
\hline
\end{tabular}

obtained for the different systems can be considered average ( 0.5 to $3 \%)$.

Scanning electron microscope (SEM) images (Figure 6) shows the cementation of soil particles. The soils stabilized with OPC and 30F1L show structures with well-cemented particles that help to obtain a uniform volumetric variation and relatively low expansion and contraction averages, while the soil stabilized with a minor proportion of alkaline cementitious material (20F1L) shows several cracks in the structure. Higher proportions of alkaline cementitious material modified the natural behaviour of the soil, which is naturally very susceptible to significant volume changes under wetting and drying cycles (according to its Unified Classification, ASTM D3282-15). In addition, the cementation observed when stabilizing the soil with $30 \mathrm{~F} 2 \mathrm{G}$ is poor, which is attributed to the collapse of the sample that prevented the completion of 12 wetting and drying cycles.
The mass loss due to wetting/drying a soil stabilized with different cementitious materials is an important property. Regarding the WDT results of this study, the reference specimen stabilized with OPC at the end of the 12 cycles has a mass loss of $3.86 \%$; the specimen of the soil stabilized with $30 \mathrm{~F} 1 \mathrm{~L}$ has a very similar mass loss of $3.74 \%$, while the soil stabilized with $20 \mathrm{~F} 1 \mathrm{~L}$ loses $10.21 \%$ of its mass after 12 cycles (Figure 7). The mass loss calculations were made using the parameters of ASTM standard D 559-15 (21), used for testing soil-cement specimens considering the weight of the water that reacts in the hydration process of OPC.

According to the Colombian standard of the National Roads Institute (43), there are two soilcement classes depending on the design criteria for the mixture: soil-cement durability (SC-D) and soilcement durability-resistance (SC-R) (Table 4). Based on the above, clayey soil A-7-5 stabilized with alkaline cementitious material 30F1L could be a viable alternative for pavement design following durability criteria SC-D, since the mass loss of this soil is only $3.74 \%$, lower than the maximum mass loss allowed by the Colombian standards, and the mass loss of this soil is similar to that of the reference soil stabilized with OPC. In addition, the change in volume of this soil under both expansion and contraction is very similar to that of the reference soil stabilized with OPC. 

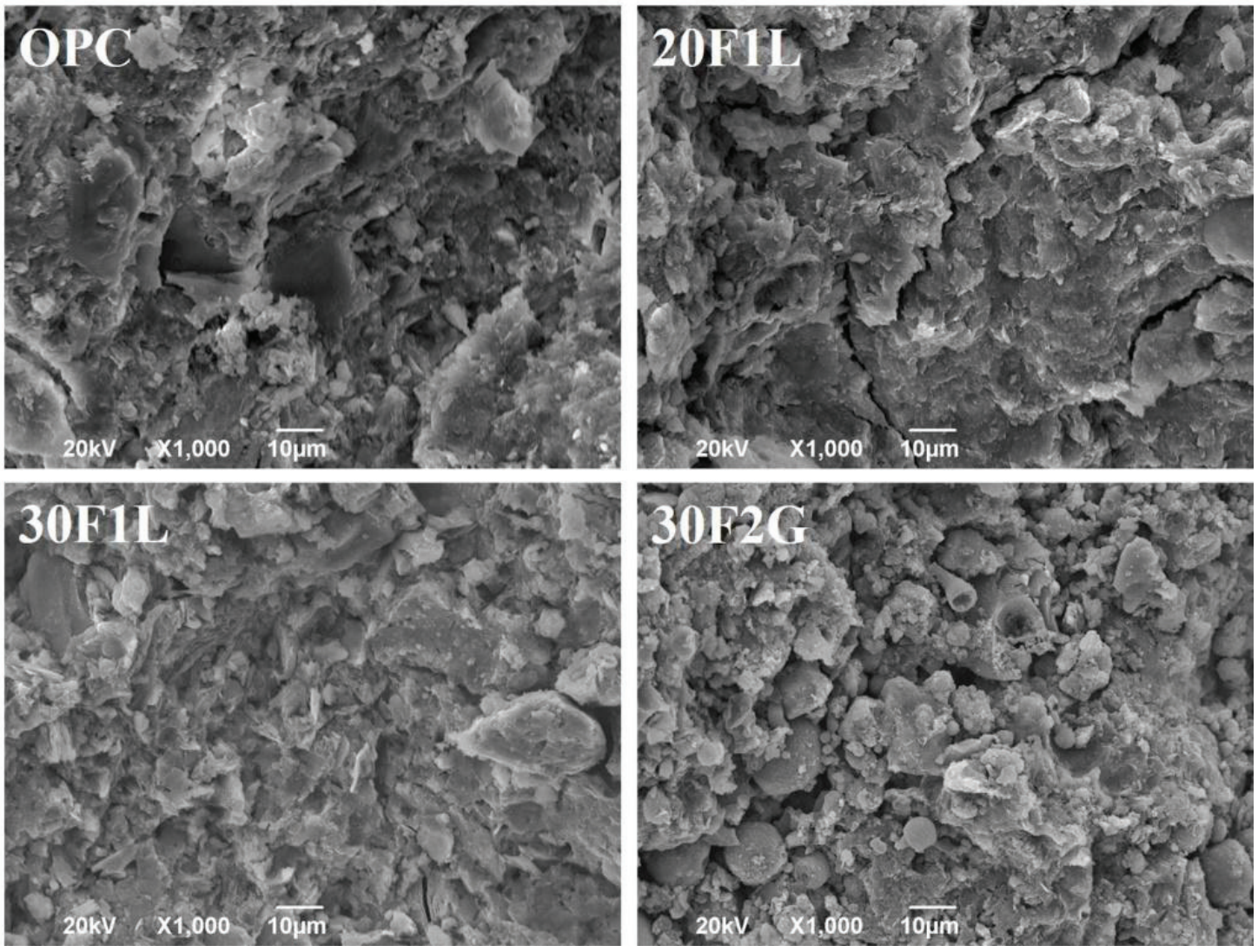

FIGURE 6. Microstructure of the soils treated with different cementitious materials.

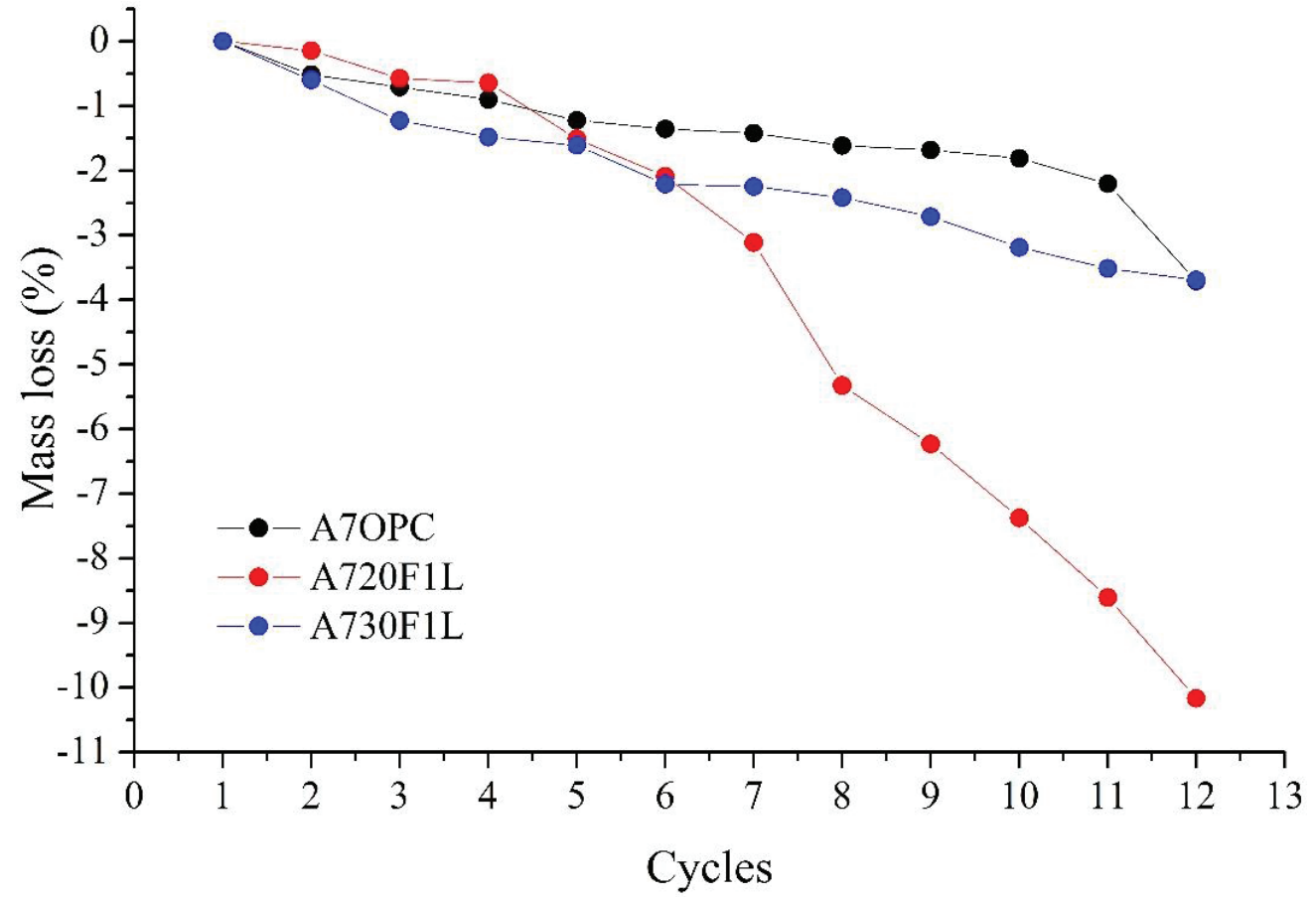

FIGURE 7. Mass loss after wetting and drying cycles. 
TABLE 4. Soil-cement design for INVIAS road applications. Adapted from (43).

\begin{tabular}{lcc}
\hline Test & SC-D & SC-R \\
\hline Durability & & \\
Maximum mass loss of the compacted mixture in wetting & 14 & 14 \\
and drying test (\%): & 10 & 10 \\
-Soils A-1; A-2-4; A-2-5; A-3 & 7 & 7 \\
-Soils A-2-6; A-2-7; A-4; A-5 & & \\
-Soils A-6; A-7 & & \\
Resistance & Increase & Increase \\
Resistance behaviour with: & Increase & \\
-Increase in OPC content & & 2.1 \\
-Increase in age & (Note 1) & 4.5 (Note 2) \\
Resistance to UCS at 7 days (MPa): & 4.5 & \\
-Minimum & & \\
-Maximum &
\end{tabular}

Soil-cement durability (SC-D) Soil-cement resistance (SC-R).

Note 1: The minimum strength is that obtained from the mixture that meets the durability criterion. Note 2: In the project, a greater resistance at 7 days can be established.

\section{CONCLUSIONS}

- The use of alkali-activated cementitious materials to stabilize soils can be a viable alternative to using traditional cementitious materials such as OPC; however, the chemical compositions of the precursor materials of the cementitious material and the soil are of crucial importance when highly alkaline activators are used. This type of soil with high iron oxide content can reduce the cementing problems of certain alkali-activated cementitious materials as long as the alkaline activator is dosed considering the proportion of soil used as a precursor material.

- The types of calcium sources in the alkaliactivated cementitious materials used in this study were essential in the stabilization of the soil. The calcium source used in cementitious material 30F1L promoted particle agglomeration and formed nucleation sites, allowing the cementitious material to interact with the soil and stabilize the soil structure.

- The proportion and type of alkali-activated cementitious material used in the soil was crucial to maintaining the structure stabilized when the specimens were subjected to wetting and drying cycles. With a proportion of 30\% alkaline cementitious material $(30 \mathrm{~F} 1 \mathrm{~L})$, it was possible to obtain percentages of change in volume and mass loss very similar to those obtained for the reference soil stabilized with OPC. This result indicates that this type of alkali-activated cementitious material can improve several important characteristics of the stabilized soil.
- The soil stabilized with $30 \%$ alkaline cementitious material $(30 \mathrm{~F} 1 \mathrm{~L})$ could be an alternative to be explored for designing pavements according to the durability criteria of the road construction regulations of Colombia. This soil meets the durability design criteria for soil-cement mixtures (SC-D). The mass loss for this cementitious material was $3.74 \%$, well below the $7 \%$ mass loss allowed by Colombian regulations, and the strength of this stabilized soil after 7 days under saturated conditions was $1.36 \mathrm{MPa}$.

\section{ACKNOWLEDGEMENTS}

The authors thank the Administrative Department of Science, Technology and Innovation (Colciencias) for the support received during the project "Prototype construction of rural housing at scale using innovative materials with low carbon footprint", contract No. 0696-313-2016, under which this research was conducted. J. F. Rivera thanks "Universidad del Valle" (Cali, Colombia) for the additional support received.

\section{REFERENCES}

1. Petry, T.M.; Little, D.N. (2002) Review of Stabilization of Clays and Expansive Soils in Pavements and Lightly Loaded Structures - History, Practice, and Future. J. Mater. Civ. Eng. 14[6], 447-460. https://doi.org/10.1061/ (ASCE)0899-1561(2002)14:6(447)

2. Behnood, A. (2018) Soil and clay stabilization with calciumand non-calcium-based additives: A state-of-the-art review of challenges, approaches and techniques. Transp. Geotech. 17, Part A, 14-32. https://doi.org/10.1016/j.trgeo.2018.08.002 
3. Shi, C.; Jiménez, A.F.; Palomo, A. (2011) New cements for the 21st century: The pursuit of an alternative to Portland cement. Cem. Concr. Res. 41[7], 750-763. https://doi.org/ 10.1016/j.cemconres.2011.03.016

4. Juenger, M.C.G.G.; Winnefeld, F.; Provis, J.L.; Ideker, J.H. (2011) Advances in alternative cementitious binders. Cem. Concr. Res. 41[12], 1232-1243. https://doi.org/10.1016/j. cemconres.2010.11.012

5. Palomo, A.; Krivenko, P.; Garcia-Lodeiro, I.; Kavalerova, E.; Maltseva, O.; Fernández-Jiménez, A. (2014) A review on alkaline activation: new analytical perspectives. Mater. Construcción. 64[315], e022. https://doi.org/10.3989/mc.2014.00314

6. Wilkinson, A.; Haque, A.; Kodikara, J. (2010) Stabilisation of clayey soils with industrial by-products: part B. Proc. Inst. Civ. Eng. - Gr. Improv. 163[13], 165-172. https://doi. org/10.1680/grim.2010.163.3.165

7. Cristelo, N.; Glendinning, S.; Fernandes, L.; Pinto, A.T.; Teixeira, A.' (2012) Effect of calcium content on soil stabilisation with alkaline activation. Constr. Build. Mater. 29, 167-174. https://doi.org/10.1016/j.conbuildmat.2011.10.049

8. Cristelo, N.; Glendinning, S.; Miranda, T.; Oliveira, D.; Silva, R. (2012) Soil stabilisation using alkaline activation of fly ash for self compacting rammed earth construction. Constr. Build. Mater. 36, 727-35. https://doi.org/10.1016/j. conbuildmat.2012.06.037

9. Sargent, P.; Hughes, P.N.; Rouainia, M.; White, M.L. (2013) The use of alkali activated waste binders in enhancing the mechanical properties and durability of soft alluvial soils. Eng. Geol. 152[1], 96-108. https://doi.org/10.1016/j.enggeo. 2012.10 .013

10. Zhang, M.; Guo, H.; El-Korchi, T.; Zhang, G.; Tao, M. (2013) Experimental feasibility study of geopolymer as the next-generation soil stabilizer. Constr. Build. Mater. 47, 1468-1478. https://doi.org/10.1016/j.conbuildmat. 2013.06.017

11. Siddiqua, S.; Barreto, P.N.M. (2018) Chemical stabilization of rammed earth using calcium carbide residue and fly ash. Constr. Build. Mater. 169, 364-71. https://doi. org/10.1016/j.conbuildmat.2018.02.209

12. Ghadir, P.; Ranjbar, N. (2018) Clayey soil stabilization using geopolymer and Portland cement. Constr. Build. Mater. 188, 361-71. https://doi.org/10.1016/j.conbuildmat. 2018.07.207

13. ASTM (American Society of Testing Materials). (2017) ASTM D6913/D6913M-17 Standard Test methods for Particle-Size Distribution (Gradation) of Soils Using sieve Analysis. https://doi.org/10.1520/D6913 D6913M-17

14. ASTM (American Society for Testing Materials). (2017) ASTM D4318 - 17e1 Standard Test Methods for Liquid Limit, Plastic Limit, and Plasticity Index of Soils. https:// doi.org/10.1520/D4318-17E01

15. ASTM (American Society of Testing Materials). (2015) ASTM D3282-15 Standard Practice for Classification of Soils and Soil-Aggregate Mixtures for Highway Construction Purposes. https://doi.org/10.1520/D3282-15

16. ASTM (American Society of Testing Materials). (2012) ASTM D1557-12e1 Standard Test Methods for Laboratory Compaction Characteristics of Soil Using Modified Effort $(56,000 \mathrm{ft}-\mathrm{lbf} / \mathrm{ft} 3 \quad(2,700[\mathrm{kN}-\mathrm{m} / \mathrm{m} 3]))$ https://doi. org/10.1520/D1557-12E01

17. Portland Cement Association. (1992) Soil-Cement Laboratory Handbook. Ed. Skokie, Illinois. 10-13 pp.

18. ASTM (American Society of Testing Materials). (2017) ASTM D1632-17 Standard Practice for Making and Curing Soil-Cement Compression and Flexure Test Specimens in the Laboratory. https://doi.org/10.1520/D1632-17

19. ASTM (American Society of Testing Materials). (2017) ASTM D1633-17 Standard Test Methods for Compressive Strength of Molded Soil-Cement Cylinders. https://doi. org/10.1520/D1633-17

20. ASTM ( American Society of Testing Materials). (2012) ASTM D1635/D1635M-12 Standard Test Method for Flexural Strength of Soil-Cement Using Simple Beam with Third-Point Loading. https://doi.org/10.1520/D1635

21. ASTM (American Society of Testing Materials). (2015) ASTM D559/D559M-15 Standard Test Methods for
Wetting and Drying Compacted Soil-Cement Mixtures. ASTM. https://doi.org/10.1520/D0559

22. Oluwatuyi, O.E.; Adeola, B.O.; Alhassan, E.A.; Nnochiri, E.S.; Modupe, A.E.; Elemile O.O; Obayanju T.; Akerele G. (2018) Ameliorating effect of milled eggshell on cement stabilized lateritic soil for highway construction. Case Stud. Constr. Mater. 9, e00191. https://doi.org/10.1016/j. cscm.2018.e00191

23. Phummiphan, I.; Horpibulsuk, S.; Rachan, R.; Arulrajah, A.; Shen, S.; Chindaprasirt, P. (2017) High Calcium Fly Ash Geopolymer Stabilized Lateritic Soil and Granulated Blast Furnace Slag Blends as a Pavement Base Material. J. Hazard. Mater. 341, 257-267. https://doi.org/10.1016/j. jhazmat.2017.07.067

24. Sharma, A.K.; Sivapullaiah, P.V. (2016) Strength development in fly ash and slag mixtures with lime. Proc. Inst. Civ. Eng. - Ground Improv. 169[3], 194-205. https://doi. org/10.1680/jgrim.14.00024

25. Osinubi, K.J. (2006) Influence of Compactive Efforts on Lime-Slag Treated Tropical Black Clay. J. Mater. Civ. Eng. 18[2], 175-181. https://doi.org/10.1061/(ASCE) 0899-1561(2006)18:2(175)

26. Lee, S.; Seo, M.D.; Kim, Y.J.; Park, H.H.; Kim, T.N.; et al. (2010) Unburned carbon removal effect on compressive strength development in a honeycomb briquette ash-based geopolymer. Int. J. Miner. Process. 97[1-4], 20-25. https:// doi.org/10.1016/j.minpro.2010.07.007

27. Shearer, C.R.; Provis, J.L.; Bernal, S.A.; Kurtis, K.E. (2016) Alkali-activation potential of biomass-coal cofired fly ash. Cem. Concr. Compos. 73, 62-74. https://doi. org/10.1016/j.cemconcomp.2016.06.014

28. Fernández-Jimenez, A.; Palomo, A. (2003) Characterisation of fly ashes. Potential reactivity as alkaline cements. Fuel. 82[18], 2259-2265. https://doi.org/10.1016/S0016-2361(03) 00194-7

29. van Deventer, J.S.J.; Provis, J.L.; Duxson, P.; Lukey, G.C. (2007) Reaction mechanisms in the geopolymeric conversion of inorganic waste to useful products. J. Hazard. Mater. 139[3], 506-513. https://doi.org/10.1016/j.jhazmat.2006.02.044

30. Lemougna, P.N.; MacKenzie, K.J.D.D.; Jameson, G.N.L.L.; Rahier, H.; Chinje Melo, U.F. (2013) The role of iron in the formation of inorganic polymers (geopolymers) from volcanic ash: a ${ }^{57} \mathrm{Fe}$ Mössbauer spectroscopy study. J. Mater. Sci. 48[15], 5280-5286. https://doi.org/10.1007/ s10853-013-7319-4

31. Choi, S.C.; Lee, W.K. (2012) Effect of $\mathrm{Fe}_{2} \mathrm{O}_{3}$ on the Physical Property of Geopolymer Paste. Adv. Mater. Res. 586, 126-129. https://doi.org/10.4028/www.scientific.net/ AMR.586.126

32. Lloyd, R.R.; Provis, J.L.; Van Deventer, J.S.J. (2009) Microscopy and microanalysis of inorganic polymer cements. 1: Remnant fly ash particles. J. Mater. Sci. 44[2], 608-619. https://doi.org/10.1007/s10853-008-3077-0

33. Chen, A.; Zhang, J. (2019) Strength and Deformation Characteristics of Silty Sand improved by Gravel. KSCE J. Civ. Eng. 23, 525-533. https://doi.org/10.1007/ s12205-018-1047-x

34. Sarmadi, M.S.; Zohrevand, P.; Rezae, M. (2019) Effect of kerosene contamination on the physical and mechanical properties of sandy soil. Innov. Infrastruct. Solut. 4[1], 7. https://doi.org/https://doi.org/10.1007/s41062-019-0196-1

35. Lee, W.K.W.; Van Deventer, J.S.J. (2002) The effect of ionic contaminants on the early-age properties of alkali-activated fly ash-based cements. Cem. Concr. Res. 32[4], 577-584. https://doi.org/10.1016/S0008-8846 (01)00724-4

36. Chindaprasirt, P.; Phoo-ngernkham, T.; Hanjitsuwan, S.; Horpibulsuk, S.; Poowancum, A.; Injorhor, B. (2018) Effect of calcium-rich compounds on setting time and strength development of alkali-activated fly ash cured at ambient temperature. Case Stud. Constr. Mater. 9, e 00198. https://doi.org/10.1016/j.cscm.2018.e00198

37. Al-Mukhtar, M.; Khattab, S.; Alcover, J.F. (2012) Microstructure and geotechnical properties of lime-treated expansive clayey soil. Eng. Geol. 139-140, 17-27. https://doi. org/10.1016/j.enggeo.2012.04.004 
38. Muntohar, A.S. (2011) Engineering characteristics of the compressed-stabilized earth brick. Constr. Build. Mater. 25[11], 4215-4220. https://doi.org/10.1016/j.conbuildmat.2011.04.061

39. Mandal, T.; Edil, T.B.; Tinjum, J.M. (2018) Study on flexural strength, modulus, and fatigue cracking of cementitiously stabilised materials. Road Mater. Pavement Des. 19[7], 1546-1562. https://doi.org/10.1080/14680629.2017.1325772

40. Kamon, M.; Gu, H.; Katsumi, T. (1999) Engineering Properties of Soil Stabilized by Ferum Lime and Use for the Application of Road Base. Soils Found. 39[1], 31-41. https://doi.org/10.3208/sandf.39.31
41. Nogami Shuji, J.; Villibor Fadul, D. (1995) Pavimentação de Baixo Custo com Solos Lateríticos ( $I^{a}$ PARTE) Sao Paulo-SP-Brasil. 240 pp. Ed. Villibor.

42. Jiménez Rojas, J.W.; Consoli, N.C.; Heineck, K.S. (2008) Durabilidad de un suelo contaminado y tratado con cemento portland. Rev. Ing. Construcción. 23[3], 163-170. https://scielo.conicyt.cl/pdf/ric/v23n3/art04. pdf

43. INVIAS (2013) Capítulo 3 Afirmados subbases y bases. Artículo 350-13 suelo-cemento. https://es.slideshare.net/ vrojas64/350-suelo-cemento-3 